\title{
IMÁGENES DEL BÍOBÍO: CULTURA POPULAR, PERIFERIAS URBANAS E INCONGRUENCIAS EN LAS CRÓNICAS DE ALFONSO ALCALDE
}

\section{BÍOBÍO IMAGES: POPULAR CULTURE, URBAN PERIPHERIES AND INCONGRUITIES IN THE ALFONSO ALCALDE CHRONICLES}

\author{
Olga Ostria Reinoso \\ Universidad del Bío-Bío \\ eostria@ubiobio.cl
}

\section{Resumen:}

Este artículo propone la lectura de una selección de textos periodístico-literarios que el multifacético escritor Alfonso Alcalde dedicó a la ciudad de Concepción y la región del Biobío. El recorrido interpretativo busca examinar determinadas expresiones de la cultura popular, las cuales configuran el particular imaginario urbano trazado en dichos escritos. El análisis implica, consecuentemente, dejar testimonio del fecundo diálogo que las crónicas, dada su condición de letras anfibias, entablan con el resto de la obra del autor.

Palabras clave: crónicas urbanas, Alcalde, Biobío, cultura popular.

\section{Abstract:}

This paper presents a critic lecture of a journalistic-literary texts selection written by Alfonso Alcalde. This multifaceted author dedicated these chronicles to Concepción city and Biobio

Recibido: 29/11/2015

Aceptado: $18 / 4 / 2016$

Region. The proposed interpretation looks for examining some popular culture expressions, which configure a particular urban 
imaginary drawing in the aforementioned texts. The analysis implies, as a result, to leave a testimony of the prolific dialogue that Alcalde's urban chronicles, as amphibious writing, start with the rest of his work.

Keywords: urban chronicles, Alcalde, Biobío, popular cultures.

Aunque es Punta Arenas la tierra que en 1921 ve nacer a Alfonso Alcalde, será Concepción su "ciudad adoptiva", su gran inspiración literaria, y Tomé (localidad costera aledaña), el refugio y constante geográfica de una vida a la que allí también decidirá dar trágico fin. No en vano, su obra lírica más ambiciosa y representativa será El panorama ante nosotros (1969), enorme poema épico consagrado a esta zona, sus aires, sus aguas, su gente.

Sin embargo, no solo de poesía vivió y murió Alcalde. El tremendamente versátil, profuso $\mathrm{y}$, en varios sentidos, marginal artista, se abocó, como pocos, a todos los géneros literarios ${ }^{1} \mathrm{y}$ dedicó, además, largos años al ejercicio del periodismo, el que no sólo constituyó un declarado nutriente de su producción narrativa y poética ${ }^{2}$, sino también engendró por sí mismo múltiples escritos vinculados a la región del Biobío. Una selección de esos textos, recuperados de un periódico local

1 Cuentos, novelas, ensayos, biografías, poemas, textos dramáticos, reportajes, crónicas, traducciones, guiones televisivos y radiofónicos son parte de la interminable obra de Alcalde, gran parte de la cual ha quedado lamentablemente en los márgenes de la memoria literaria nacional. No abundan, efectivamente, los trabajos teórico-críticos sobre sus textos. Destacamos aquí los aportes de Concha (1971 y 1973), Naín (1998), Geisse (2007) y Sepúlveda (2010). Esta investigación ha aspirado, en tal dirección, a contribuir a la difusión y valoración del escritor desde una faceta aún más desconocida: su producción periodística.

${ }^{2} \mathrm{Al}$ respecto, señaló el autor:’El periodismo, hasta hoydía, me nutrío de materia prima constante, de seres reales, directos, aliterarios." ("Impresiones" 372). 
Olga Ostria Reinoso. Imágenes del BíoBío: Cultura popular, periferias urbanas e incongruencias en las crónicas de Alfonso Alcalde

(publicados entre 1966 y 1992) ( $^{3}$ e inéditos en formato libro, es la que aquí examinamos desde su condición de "periodismo narrativo" o "crónicas urbanas". En ella el autor proyecta un particular imaginario urbano-popular de esta parte del sur de Chile, que proponemos recorrer a través de una lectura que implica, consecuentemente, visibilizar los nexos entre las letras periodísticas y la imaginación literaria alcaldeana, esa mixtura de registros, géneros y tradiciones escriturales que configura los relatos a estudiar y, de esa forma, dejar testimonio del fecundo dialogismo a través del cual ellos participan de la obra total del autor.

\section{Sobre cultura popular y crónica urbana en Alcalde}

El término "popular" sigue generando conflictos, tensiones, sospechas inclusive. Se trata, en verdad, de un concepto controvertido $\mathrm{y}$, en la cotidianidad, frecuentemente manipulado. A menudo, y todavía asociada, por oposición a la cultura, a calificativos como inculto, rural, vernáculo, oral, folclórico, subalterno, por nombrar algunos, la categoría es mayormente concebida hoy como aquello que ha nacido del pueblo pero también que el pueblo o, mejor, los sectores no privilegiados, han adoptado, hecho propio y "consumido". Así, hemos de pensar aquí lo popular en la cultura y en la literatura desde una perspectiva relacional, es decir, desde sus dinámicas de circulación cultural, a partir de las cuales esta se (re)conforma; desde sus tránsitos e intersecciones con la cultura hegemónica ${ }^{4}$, con la llamada alta cultura y con la complejidad

\footnotetext{
${ }^{3}$ Dicha labor constituyó parte del proyecto de investigación "El periodismo literario de Alfonso Alcalde" (DIUBB 130926 3/R 2013), a través del cual se compiló textos del escritor publicados en el diario El Sur de Concepción, durante los periodos 1966-1972 y 1988-1992.

${ }^{4}$ Nos guiamos aquí por la interpretación que de "hegemonía" plantea García Canclini: "un proceso de dirección política e ideológica en el que una clase o sector logra una apropiación preferencial de las instancias de poder en alianza
} 
de lo urbano y lo masivo. Considerando, entonces, las relaciones de influencia y consenso, o bien, de oposición y apropiación que en tales procesos se generan, asumimos el ámbito de la cultura en las sociedades actuales como un "espacio estratégico de la contradicción" (Martín Barbero 67). De modo que optamos por una mirada que persigue exteriorizar los conflictos que allí se articulan: la lógica y la réplica tanto de la dominación como de la resistencia.

En esa línea de reflexión, hemos procurado en este trabajo entrever en los textos aquellas expresiones populares residuales (Williams) que permanecen a pesar y con las múltiples transformaciones que impone la modernidad. Son tales aspectos, en concreto, la tradición oral, la comicidad y sus articulaciones circenses, y el melodrama, los que intervienen en la configuración del imaginario urbano-popular alcaldeano en estudio y a los cuales nos abocamos en estas páginas.

Es interesante anotar, desde este horizonte, dos últimas reflexiones en torno al autor. Convengamos, en primer término, que la cultura popular es visible, toma cuerpo, por lo menos en la literatura, a través de la intermediación de un letrado. Esta se lleva a cabo desde un determinado punto de vista, que en Alcalde podría corresponder a un proyecto escritural que ha sido vinculado a un "realismo popular", manifestado principalmente en sus narraciones, y entendido éste como una "inmersión profunda y genuina en la realidad del pueblo chileno" (Memoria chilena), pero también a un "surrealismo popular" (Geisse, Consagración 22), por la inclusión de situaciones irreales, delirantes o excéntricas. Se trata, en todo caso, de una propuesta dedicada a la visión de mundo de los grupos más precarios: "su capacidad de improvisar, la presencia del humor, la relevancia

con otras clases, admitiendo espacios donde los grupos subalternos desarrollan prácticas independientes y no siempre funcionales para la reproducción del sistema" (22). 
Olga Ostria Reinoso. Imágenes del BíoBío: Cultura popular, periferias urbanas e incongruencias en las crónicas de Alfonso Alcalde

de la solidaridad, el amor por las comidas y bebidas" (21), que constituye, en fin, un perpetuo "intento de atrapar experiencias populares" (Concha, Historias12), a las cuales el escritor se volcó a investigar sistemáticamente ${ }^{5}$. De origen humilde, Alcalde no es, pues, un letrado de las altas esferas. Proviene, como afirma Lucía Guerra a propósito de Arlt, "de la pequeña burguesía en posición fronteriza con la pobreza" (110); es precisamente un hombre del "pueblo" que hace suyas las letras y la poesía, de manera que bien encarna esta comprensión de lo popular, como lugar de cruces, revueltas y apropiaciones.

Por otra parte, concebimos la crónica como una manifestación literaria privilegiada a la hora de configurar la cultura popular de carácter urbano. Su flexibilidad y heterogeneidad discursiva, su condición de escritura fronteriza y dialógica le permiten conjugar reflexiones de diversa índole, incluir distintos registros y géneros, oscilar entre lo objetivo y subjetivo, entre la realidad y la imaginación, y yuxtaponer, desde luego, lo canónico a lo marginal. Así, articula de modo natural (lo que no significa exento de contrastes) la multiplicidad de relatos a partir de los cuales es factible desentrañar las transformaciones socio-culturales propias de las ciudades modernas y las interacciones de la cultura que allí se expresan (Ostria O. 112) ${ }^{6}$. Curiosamente, Alcalde personifica

\footnotetext{
${ }^{5}$ En efecto, se consideraba Alcalde un auténtico investigador de los usos y costumbres del pueblo chileno: "He salido otra vez a encontrar al pueblo, sintiendo una fuerza natural para incorporarme a él: esa es una de las condiciones para un escritor popular. Ese es el planteamiento nuestro, pretendemos interpretar a ciertos sectores populares por estar dentro, no como una curiosidad" (De la Fuente 44).

6 Existe actualmente bastante bibliografía sobre la naturaleza y las manifestaciones de la crónica urbana hispanoamericana. Véase, por ejemplo: Albert Chillón (1999). Literatura y Periodismo. Una tradición de relaciones promiscuas. Barcelona: Universidad Autónoma de Barcelona; Susana Rotker (2006). La invención de la crónica. México: FCE; Jezreel Salazar. La Crónica: Una Estética de la Transgresión. Razón y Palabra [en línea]. http://www.razonypalabra.org.mx/anteriores/n47/jsalazar.html; Darío
} 
también la actitud de estos "ornitorrincos de la prosa" (Villoro 14) cuando acusa, por ejemplo, haber leído "de un tirón -que es como comerse un pollo crudo- desde un tal Homero hasta el himno del Colo-Colo"7 ("Impresiones" 371).

\section{Cocimientos, tabernas y máscaras}

Un elemento fundamental en la configuración de esos verdaderos montajes discursivos que son las crónicas de Alcalde, lo constituyen los espacios o ambientes populares, ciertamente recurrentes en su producción toda: barrios y poblaciones e incluso basurales, pero especialmente bares, "picadas", delinearán la atmósfera predilecta para retratar el derrotismo y, al mismo tiempo, la vitalidad de los más desposeídos. Se trata de "merenderos, chincheles, borracherías" que, para el autor, "son como las cebollas: giran alrededor de su propio misterio dando vueltas y vueltas" (Alcalde, "Merenderos" 2), y donde el recetario de cocina popular acusa el carácter dionisiaco igualmente transversal en la obra del escritor tomecino ${ }^{8}$. Las crónicas gastronómico-populares en las que se apologiza la comida -los asados de cordero, los mariscales y caldillos, los pescados a las brasas, las patitas de chancho, las pichangas- que se elabora en las zonas costeras y mineras de la

Jaramillo Agudelo (ed.). 2011. Antología de la crónica latinoamericana actual. Madrid: Alfaguara.

${ }^{7}$ Esa capacidad de aunar discursos se ve reflejada también en los numerosos collages del autor, actividad en la que se inició a mediados de los años 60 y que se condice plenamente con la extraordinaria heterogeneidad de su proyecto literario y de su propia existencia: Alcalde experimentó los más variados oficios (desde ayudante de panadero y diarero, hasta cuervo de una empresa funeraria y traficante de caballos en el Matto Grosso).

${ }^{8}$ Admirador de De Rokha, Alcalde escribe bajo la inspiración de la Epopeya de las bebidas y comidas de Chile (1965, Santiago: Editorial Universitaria), el reportaje Comidas y bebidas de Chile (1972), editado como parte de la colección Nosotros los chilenos. Este análisis contempla crónicas previas y posteriores a tal publicación, en las cuales se encuentran, respectivamente, antecedentes al recetario de Quimantú, o bien, revisitas y actualizaciones. 
Olga Ostria Reinoso. Imágenes del BíoBío: Cultura popular, periferias urbanas e incongruencias en las crónicas de Alfonso Alcalde

región, pero también en Arauco y las periferias de Concepción, darán cuenta de la agudeza, la creatividad y el humor vital de las clases populares. En efecto, las ingeniosas preparaciones, más exuberantes que "tristes y sombrías" ("La sabrosa" 4), patentizan su capacidad de ir contra la adversidad y el hambre. No obstante, es sobre todo a través del lenguaje, en estos textos rescatado, que la imaginación popular se ve celebrada. Así, son notables las denominaciones de algunos recomendados platos entre ellos, "las machas a lo macho", la "Huañaca" (caldo de papas), El chanchito abstemio- y tragos, como el "tate quieto", el "chingolito" (aguardiente con Bilz) y la "sopa de la novia" (hecha de picorocos ${ }^{9}$ ): "Detrás de cada nombre -declara el enunciador-, un misterio: el de los sabores y los aromas, el capital espiritual de la gastronomía" ("Merenderos" 1). Destacan igualmente los sobrenombres a cocciones más tradicionales, como la butifarra, llamada acá "guata rellena", por elaborarse con "todo el tripaje del cordero, pan leche y huevo"; o bien, el cochayuyo, más conocido en la zona minera como "colloi", y las pantrucas, cuya "masa convenientemente sobada se echa luego a la olla hirviendo", por lo cual se les apoda "tíremelas a la olla" ("La sabrosa" 5). Y, por supuesto, hay que añadir los memorables títulos de los propios comederos -que no ostentan letreros, pues "van de boca en boca" ("Merenderos" 3): "el Chez Vomite, literalmente traducido como El vómito, El Paleta, El palacio de las moscas, El guata amarilla, El pata con calcetines" (ídem), "El patá en la raja", "Donde mueren los valientes y La Poto bonito" (Comidas, 6).

Sin duda, lo popular en Alcalde se revela muy especialmente en el tratamiento del lenguaje que lleva a cabo una constante representación de la oralidad a través de deformaciones sintácticas, de desarticulaciones y figuras que producen los efectos del "hablar" rápido y del "mal hablar", que, en fin, acercan las palabras a las formas de pronunciación

\footnotetext{
${ }^{9}$ Mariscos famosos por acrecentar la potencia sexual.
} 
coloquiales, rústicas o vulgares, y que se hallan presentes en el discurso del enunciador, ya sea en relatos subordinados o en el principal (Ostria M.), en este caso mediante un estilo indirecto libre, característico de la crónica urbana. En tal sentido, "junto con las recetas [Alcalde] coge también la sabrosura del habla popular, la picardía, el amor a la vida, la sabiduría natural" (Vidal 14), haciéndolas parte de su propio discurso: "[...] también se reflejan en el arte culinario algunas de las características de los chilenos: un poco al lote, intuitivos, con buena cachativa y un excelente olfatímetro para descubrir dónde se preparan los platos para chuparse los dedos" (Alcalde, "Merenderos" 3).

Ahora bien, es a todas luces el doble sentido el que se lleva el protagonismo en este aspecto del análisis, y del que se hallan cargadas estas modalizaciones del habla, a partir del chiste y la (a veces) sutil grosería. En ellas se evidencia el juego de palabras y, con él, el desplazamiento de sus sentidos. Conectados con imágenes grotescas (en la comprensión bajtiniana de la expresión), muchos de los nombres mencionados ligan la comida con el cuerpo, con la vida material y con la vida sexual: las tripas, la guata, el vómito, el "poto". La fuerza reproductiva de los alimentos se ve exhibida, desde esta perspectiva, en los célebres "caldos criatureros" o "melliceros", llamados así, naturalmente, por sus poderes afrodisiacos y fertilizadores. Mediante ciertos elementos fundamentales de dicho sistema de imágenes como "el coito, el embarazo, el despedazamiento corporal, etc., con toda su materialidad inmediata" (Bajtin 29), asociados, desde luego, a "la comida, la bebida y la satisfacción de las necesidades naturales, el cuerpo revela su esencia como principio en crecimiento que traspasa sus propios límites" (30). En el fondo de estos "rebajamientos" y obscenidades $^{10}$ reside además la risa del pueblo, la intención

\footnotetext{
${ }^{10}$ Ese "humorismo truculento y descendente orientado hacia la hez", como escribía Alone en una crítica a El Auriga Tristán Cardenilla, es un rasgo frecuente en la cuentística del autor. No en vano la advertencia del propio
} 
Olga Ostria Reinoso. Imágenes del BíoBío: Cultura popular, periferias urbanas e incongruencias en las crónicas de Alfonso Alcalde

burlesca, que constituye su médula y le confiere toda su energía. Siguiendo al teórico ruso, se trata ésta de una disposición que desafía la seriedad del mundo oficial y que a través de diversos tipos de máscaras, en este caso, lingüísticas (los apodos), expresan la negación popular a una identidad unívoca, pero, más aún, una capacidad de transformar lo dado, lo impuesto, en un intento tanto de liberación de los miedos, como de resistencia, donde se manifiesta una fuerza vital admirable: "el movimiento de la metamorfosis y las reencarnaciones, que es el movimiento de la vida" (Martín Barbero 74).

Dichas máscaras o disfraces que caracterizan tal cultura de la taberna que Alcalde gusta de retratar, constituyen además un "estratagema de encubrimiento y disimulación, de engaño a la autoridad y volteamiento de las jerarquías" (ídem):

Las mujeres lo preparan mezclando erizos, cholguas, machas, ulte, piure, cebolla pluma, cilantro, limón y un poco de ají. Tienen una maestría extraordinaria para darle el sabor preciso, inconfundible. El cliente tiene derecho a servirse una maliciosa tacita de "té frío" (vino blanco) o "café" (vino tinto) para eludir las disposiciones municipales vigentes. Las dueñas de casa pueden intentar preparar este plato en su hogar, puesto que la fórmula no es secreta. Pero jamás les resultará igual. Los penquistas optan por comprar "tantas porciones como invitados

escritor que da inicio a Las aventuras de El Salustio y El Trúbico (1973): “De la cintura para arriba y de la cintura para abajo, los cuentos populares de antaño escarbaron el alma, los trabajos y la conducta de nuestros compatriotas. [...] El Salustio y El Trúbico [...] se ponen ahora a recorrer estas impertinencias, estas goloserías materiales, estas tribulaciones que escuecen otra realidad que no por verdadera es menos cierta. [...] Se trata, entonces, de movilizar esta fortuna del humor que nos cayó en gracia para la desdicha de los tontos graves y los huevones a la vela" (9-11). 
tengas a la mesa" y llevan su invalorable tesoro gastronómico en transparentes bolsa nilón que compran en el mismo lugar (Alcalde, "La sabrosa"4).

Junto con el registro de una especie de código secreto de parroquianos, en el que las palabras son antifaces, este extracto permite observar cómo los platos y bebidas son concebidos como patrimonio de la cultura de la cual provienen, y de la que se hallan impregnados: irreproducibles por otras manos no pueden sino adquirirse más que en una bolsa de plástico. La paradoja (tesoro (riqueza, opulencia) / bolsa nilón (vinculada a la escasez y la simpleza) evidencia una valoración social de parte del texto, que exalta el origen popular ("el absurdo tesoro de la miseria"). Los alimentos, sus métodos y envases, poseen, pues, propiedades simbólicas, significados sociales en estos textos, ligados al sentido de pertenencia de los grupos populares. Ciertamente, "el lenguaje de la alimentación es vasto y profundo y compromete una forma de "pensarnos" a nosotros mismos" (Montecinos 26) y, por consiguiente, de concebirnos en relación a otros, a nuestras distancias. Por ello también es que Alcalde subraya el dónde se cocina, que tampoco es ingenuo o anecdótico, esos lugares orilleros, pero exclusivos, especialistas en platos que "no se encuentran en los restaurantes" ("La sabrosa" 4) o alcoholes que sólo se pueden hallar "en los bares y bodegas más o menos clandestinos" (5).

De esta forma, mediante la presentación de las singulares recetas, bebidas y del repertorio de "picadas", los textos alcaldeanos tejen un vínculo entre la comida y los sujetos populares que realza no sólo una manera especial de preparar los alimentos sino además de compartirlos, con lo cual se pone en relieve la significación del lazo social que ellos convocan. Así, por ejemplo, para la muerte del chancho: 
Se reúnen diez o quince compadres y se hacen cargo de la muerte de un cerdo que si está gordo no baja nunca de los 80 kilos. La fiesta se prolonga unos tres días con sus correspondientes noches en que se toma y se come por el campeonato. Pronto se notician los artistas del barrio: los guitarristas y los cantores, y el grupo se agranda mientras comienzan a salir las prietas, los chicharrones y se dora el asado y se fríen en grasa las sopaipillas que parecen platos. (Comidas 20).

O bien, se comenta con soltura que "Don Eneas que vive en el camino a Cocholgüe [...] es bueno para la guitarra y el acordeón y le gusta amenizar la fiesta interpretando canciones y cuecas que son de su propia cosecha"; que Armando Cares, de Tomé, es un "hombre ducho en el oficio" de la cocina; que "Las [mejores] longanizas caseras vienen de Carampangue y las vende Carlos Guajardo; y que "los cocimientos de don Pedro hacen época como los chunchules a la parrilla del Bar Democrático tomecino que se sirve con vino Mangarral, grueso y amistoso" ("La sabrosa" 4).

La familiaridad, la cercanía con la que se presenta y recomienda a los anfitriones y cocineros de los mesones favorece la conformación de aquel sentido de comunidad en torno a la comida y al acto de sentarse a comer, que resulta finalmente en la representación de una permanente relación de confraternidad entre los comensales ${ }^{11}$.

\footnotetext{
${ }^{11}$ Percepción que está igualmente presente tanto en la cuentística de Alcalde: "El valor fundamental es el de la fraternidad popular que irradia y se acrecienta en medio de las lágrimas, junto al vino, en el habla sencilla y directa de sus personajes" (Concha, El Auriga 15); como en su poesía: En el Panorama "Alcalde elabora un sujeto poético plural: nosotros. [...] inventa la región del Bío-Bío como una comunidad de sentido [...] que llama una y otra vez con la palabra: "vecino", "vecina" (Sepúlveda 106).
} 


\section{Circo, radio y melodrama.}

El rescate de la lengua del pueblo observado en las citadas crónicas de Alcalde (que permite vislumbrar un intento de recuperación del discurso de la picaresca) revela una concepción estética de la cultura cómica popular que es congruente con los textos más estrictamente ficcionales del autor, y se sustenta, como hemos advertido, en la noción de lo grotesco, la burla y la máscara, pero también en el universo del circo. Por ello es que en múltiples cuentos del escritor habitan trapecistas, mujeres de goma, payasos de las más diversas clases, marginados alegres cuya existencia es un continuo intento de superación de las penurias ${ }^{12}$. Más que un escenario concreto, el circo constituye una atmósfera y, especialmente, una simbología de vida, unas "huellas secretas en los individuos" (Concha, El auriga 11), que articulan en Alcalde su visión tragicómica y contradictoria del mundo.

Dicha mirada se manifiesta de manera espléndida en la crónica "Un pintor ambulante" (1989), que permite además apreciar imágenes de uno de los sitios predilectos del cronista: Tomé. La historia de Alejandro Reyes, versará sobre sus trágicos inicios y sus variados oficios. Proveniente de los escombros, las "nubes de polvo, los fierros retorcidos, [...] desde el fondo de la desgracia y [...] las tumbas colectivas" (2) de un Penco (devastado por el terremoto de 1939), el personaje se instala en la caleta, primero en una "calle poética: Los suspiros" (2) y luego en Cerro Alegre, cuya casa "también tenía su encanto: El techo dejaba pasar la

\footnotetext{
${ }^{12}$ Soy uno de ellos [...] puedo estar en cualquier parte como en mi casa, con cualquiera de ellos, que son los más marginados de todos los marginados. No tienen nada. Solamente tienen la transparencia de la fantasía de vivir" (Cit. en Geisse, "La consagración").
} 
Olga Ostria Reinoso. Imágenes del BíoBío: Cultura popular, periferias urbanas e incongruencias en las crónicas de Alfonso Alcalde

luz de las estrellas y las gotas interminables de los inviernos tomecinos" (3). Luego de laborar en el puerto -cuyas atmósferas le parecen al escritor como las de los westerns-, el obrero, sastre, peluquero logrará dedicarse a su verdadera vocación: la pintura. Junto a otros artistas, organiza el Círculo de Bellas Artes en Tomé. "Atriles y paletas en mano salen a recorrer los cerros: atardeceres gloriosos, vericuetos de las calles donde se escuchan hasta los pasos que nunca llegaron, niños dulcificados por la pobreza y la alegría de estar vivos" (3). Los pintores despiertan suspicacias en los vecinos quienes "los confunden con ingenieros encargados de medir la dudosa frontera de sus sitios" (3). En radical idealismo, deciden entonces regalar sus obras a la gente, que las reciben con todavía más sospecha: "¡Tanto color en tan poco espacio!" (3) Todo es arte, nobleza y romanticismo hasta que Reyes advierte que los cuadros obsequiados sirven de "¡comedero a pollos y gallinas!”, "sus árboles humanos que surgen como un himno y esos rostros que hablan de amores y tristezas, quedan picoteados en medio de las risas" (3) de los pobladores. Mientras las gallinas dan muestras de felicidad, otro de los cuadros aparece cubriendo el vacío de una ventana quebrada.

Brota, como vemos, la figura circense donde hilaridad y patetismo conviven en un mismo rostro: sistema de contrastes a través del cual hallan configuración las incongruencias y desencuentros de una sociedad fracturada. Desde allí, el escrito suscita naturalmente la reflexión sobre la futilidad del arte en la miseria o, más aún, sobre cómo el pueblo se mofa de lo que se ha erigido en las alturas como ARTE. En aquellas manos se transfiguran y desacralizan los discursos oficiales y/o elevados, quedando dotados de nuevos sentidos y usos. Se trata de una lógica y un espíritu que se replican, como veremos, en otros textos de este estudio. 
Otro personaje que expresa dicha cosmovisión es el legendario payador penquista Críspulo Gándara, quien es retratado en una crónica del setenta como un verdadero personaje de circo, el rey de la juerga, pero a estas alturas, pobre y olvidado. "Soy el roto más botado del mundo"-explica- "Con los ojos apagados y la mirada triste, recordando sus éxitos de antaño, cuando fue el monarca penquista" (Alcalde, "Críspulo" 9). Se evoca en estas líneas el Concepción periférico, excéntrico y noctámbulo: En el día "La ciudad que duerme [...] y el mercado que parece una chingana. Pero en la noche brilla una vida diferente. Se organizan fiestas y tomateras de nunca acabar, en las que el joven Críspulo es el animador obligado" (ídem). El artista en cuestión, que "impresiona por su figura maciza y esos ojos que parece que se le fueran a salir del entusiasmo", se aventura por un tiempo a la capital, pero "el sur lo atrae de nuevo y regresa a su tierra natal" donde "abre las puertas de [el bar] "El jote", de gloriosa memoria en el ámbito trasnochador penquista, [famoso por] su vino enfrutillado y su canario. Punto de reunión obligado para los políticos, artistas: gente humilde y encopetada. [...] Era emocionante ver juntos a un cochero y un palogrueso" (ídem)- se acuerda Gándara en la voz de Alcalde. Privilegiando la construcción de la memoria, este retrato de la derrota ensalza, no obstante, la bohemia y la taberna como lugar donde se tienden puentes, se mezclan las palabras, los orígenes y se cuece el encuentro con lo otro.

El relato popular y los modos de narrar en la cultura no letrada encuentran, de esta manera, una posición predominante en las letras periodístico-literarias de Alcalde, como tema y como encarnación escritural. En ese marco, se halla asimismo la lúdica crónica "Días de radio", donde el autor plasma algunas de sus vivencias en este medio de comunicación ${ }^{13}$ profundamente conectado con expresiones populares donde persisten las

\footnotetext{
13 Alcalde fue radio controlador de la radio "Simón Bolívar" en aquellos años.
} 
Olga Ostria Reinoso. Imágenes del BíoBío: Cultura popular, periferias urbanas e incongruencias en las crónicas de Alfonso Alcalde

tradiciones orales, como los mismos payadores, el circo criollo y el folletín.

En la ciudad, la radio deviene mediadora de la experiencia citadina para los inmigrantes rurales, en la medida en que empalma imágenes y expresiones de la cultura campesina con el mundo urbano. Mediante sus radioteatros, actuaciones y transmisiones en vivo, la radio entraña el gesto oral en sus modos de contar, que es siempre un contar $a$, por su accesibilidad a la participación del oyente, y en consecuencia, a la interrelación constante entre el relator y sus auditores. Constituyen, pues, formas colectivas de narrar y también de escuchar en "voz alta", es decir, de una escucha del todo participativa, una verdadera retroalimentación que suscita diálogos entre el público y el narrador e improvisaciones en los actores y locutores. Dinámicas que, en términos linguiísticos, incorporan, ciertamente, la fonética, el léxico y la sintaxis tanto del campo como de la calle.

Todos esos aspectos se incorporan en el texto citado, que en actitud nostálgica, procura plasmar los albores de la radiotelefonía penquista de los años 50, ese "mundo de fantasía que giraba alrededor de un micrófono" (5) y ante el cual la gente "no podía ocultar su asombro": ¿Cómo se producía el milagro?" (4). En aquella estación -ubicada en la calle Rengo- trabajaban unos "románticos muchachos" que "eran los regalones de la ciudad. Apenas llegaban al bar London que funcionaba en un sótano, caían como del cielo varias botellas de pipeño color ámbar" (4). Con malicia inocente, el enunciador relata una serie de anécdotas que rememoran un mundo casi infantil, travieso, pícaro que suele girar en torno a las bebidas alegres. Así, por ejemplo, asoma la historia del "Fauno", reportero que dormía en la estación y era el más veloz en la digitación: éste "terminaba un día de redactar la segunda carilla cuando uno de sus dedos quedó suspendido en el aire, y dijo: 'Parece que me vino un ataque de poliomelitis'. [El compañero] comprendió la indirecta 
y le mandó a buscar una cerveza bien helada. El mal desapareció como por encanto. Pero luego tuvo una recaída en las páginas cuatro y seis" (4). El tono prevalece en el relato de

un concurso destinado a encontrar el mejor cantante de la provincia, [para el que] Se presentaron 20 candidatos, entre ellas "Selva Moreno", seudónimo de la sobrina de una señora que tenía un bar-restaurante en la calle Maipú. Decir que desafinaba sería una calumnia. Parecía un criadero de gallos y escucharla era como si alguien pidiera socorro en un asalto (4).

La comparación desplegada aquí permite notar cómo se pone escena, justamente, la conexión del imaginario rural con el urbano: "el canto" los gallos y los gritos de la calle. Para comer, beber gratis y divertirse un poco, el equipo radial no encuentra nada mejor ni más hilarante que malversar la votación del auditorio, de modo que para la final del certamen "Selva Moreno" ganaba "por una mayoría abrumadora de votos". [...] De inmediato de escuchó un bramido entre los asistentes al viejo cine Rex y empezaron a volar las butacas [...] en medio de la lluvia de botellas y procacidades antifamiliares" (5).

Cartografiando el Concepción popular de entonces, el texto registra con continuos guiños irónicos aquella intervención de los radioescuchas, llevada a máximos volúmenes. El empleo de términos cultos ("procacidades anti familiares") en el contexto del escándalo popular produce un efecto irrisorio basado en el contraste de la grandilocuencia y lo que se considera "civilizado", las buenas costumbres, frente a la barbarie, el salvajismo de la masa irracional caótica, o el mal gusto del pueblo. 
Olga Ostria Reinoso. Imágenes del BíoBío: Cultura popular, periferias urbanas e incongruencias en las crónicas de Alfonso Alcalde

La narración insistirá en esa táctica a través de la siguiente anécdota de una emisora de Talcahuano que "vivía entonces su incipiente desarrollo industrial":

Se organizó un conjunto de radioteatro en que participaron Brisolia Herrera, Aida Garcés y tantos otros artistas que después tomarían exitosos rumbos. Se estrenaron obras de Sartre, Camus y Lope de Vega en circunstancias que el nivel de la audiencia estaba a la altura de los chascarros de "Los Huasos Cochinos". Un auditor de tales dramas no ocultó su asombro diciendo: “¡Qué raro! Llegó al puerto una compañía de radioteatro que habla en polaco. [...] Hablan puras 'huarifaifas' de la muerte y el alma y otras payasadas (5).

La riqueza de posibilidades discursivas de la crónica como tipo de texto permite la escenificación de este juego de registros y, con él, del choque entre los estereotipos culturales. A través de un humor en apariencia anodino, el escrito se burla, por una parte, de la ignorancia e ingenuidad de quienes no conocen de grandes asuntos y confunden los serios vocablos con lenguas extranjeras; y por otro, de la solemnidad, la ambición educadora idealista de aquellos que pretenden acercar la poesía, la cultura y el arte al pueblo. Se pone de manifiesto, así, la incomprensión total entre ambos universos que, en definitiva, hablan distintos idiomas. En igual sintonía, se testimonia sobre el programa del profesor Carlos Olivier Schneider, "historiador, sociólogo, investigador"; espacio que se presentaba como "una obra cultural y de patrimonio, [que buscaba enseñar] a amar el solar de los mayores", pero titulado nada menos que "Del tiempo del Ñauca" (5).

Valiéndose de una variada dotación de bromas, ironías y tenues sarcasmo, Alcalde tiende, en 
suma, a transparentar en esta crónica las profundas grietas socioculturales de la sociedad chilena, que se ven expuestas gracias a las conexiones culturales que la radio fomenta.

Pero el escritor no se queda en la exteriorización de aquellos abismos. En este texto y su contexto -según él, "Nada que ver con la cultura"- y previo al nacimiento de la Radio Universidad cuando se desarrollará la radiotelefonía a un nivel "ascendente, cultural", consideremos a un último personaje, Sergio Pineda, locutor, quien en esos tiempos:

daba cuenta de los sucesos más importantes en radio "El sur". Luego de una breve pausa [solía comentar]: Lo que termino de leer no es efectivo. La verdad de los hechos es la siguiente: Y entonces daba una versión estrictamente personal de lo ocurrido. Es decir, tenía un diario propio. $\mathrm{Su}$ rotundidad era temible: otra vez he leído una falacia, aseguraba, para entregar su visión de los sucesos (5).

Circo pobre, plagada de bufones, farsas y chascarros a la chilena, este territorio de mediación que constituye la radio (y la crónica urbana) posibilita además la invención de los "hechos", la resignificación de los "noticias", dándose así rienda suelta a la creatividad y la libertad del mundo no oficial. La imaginación se toma el poder en esta historia en la que el discurso hegemónico, "los sucesos importantes", se modifican, se disfrazan socarronamente, con impecable desfachatez, con tal descaro que parece una tomada de pelo o bien un relato inventado por completo. La falta de seriedad, de "profesionalismo" del protagonista constituye asimismo un gesto que desafía al periodismo "objetivo", tradicional, y a la cultura, a la que, otra vez, se enlaza con seriedad, acartonamiento y academia, por 
Olga Ostria Reinoso. Imágenes del BíoBío: Cultura popular, periferias urbanas e incongruencias en las crónicas de Alfonso Alcalde

cierto. Si la industria mediática transforma la experiencia de la vida popular volviéndola uno de sus modos de existencia, este texto simboliza, en síntesis, una respuesta de dichos modos de existencia populares-urbanos a la industria de los medios, que patentiza su capacidad de empoderarse de lo masivo, de transfigurar el discurso y, por qué no, la realidad.

La crónica alcaldeana monta, en definitiva, la interacción entre los mundos culturales, incorporando sus imaginarios, visiones, lenguajes, pero revela una notable tendencia a exaltar la perspectiva popular y las vías en que el pueblo deforma los temas insignes, profana los altos modelos culturales, su lenguaje, y erige las vidas marginadas en versiones de un mundo mucho más encantador, fascinante y libre.

\subsection{Algo de melodrama.}

Muy vinculadas, pues, en sus estilos de narrar lo popular, la radio y la crónica resultan hermanadas también en sus antecedentes, tales como la literatura de cordel y el folletín; géneros que hacen posible el tránsito de lo oral a lo escrito originando otro tipo de relación lectora-, que se hallan, además, a medio andar entre la información y la ficción, y que incorporan, por último, el melodrama como un elemento crucial de configuración de los relatos ${ }^{14}$. No es de extrañar, por tanto, que éste se haga espacio en los textos referenciales alcaldeanos y en aquellas confluencias entre lo popular-urbano-masivo y la cultura letrada, que dichos escritos despliegan. Así ocurre en el hermoso texto titulado "Doña Leo y sus 140 maridos" (1989)

14 Dada su forma de vivir osadamente, fuera de la ley, los bandidos son glorificados por la literatura de cordel. Tanto ellos como los crímenes pasionales y los célebres robos, constituyen tópicos en muchas de las rescatadas crónicas de Alfonso Alcalde, las que por objetivos y espacio no pueden ser examinadas plenamente en este artículo. En su novela Puertas Adentro (1962), el escritor reactualiza, asimismo, la tradición folletinesca de entregas semanales. 
que se ambienta en el "casi mitológico Barrio chino de Lirquén" (4).

Descubierta por Alcalde para protagonizar un programa televisivo en el que se le buscaría su alma gemela (especie de antecedente del actual reality show), la retratada, una "mujer baja, llamativa, bastante maquillada y con un anillo en cada dedo", y dueña del restaurante marino La Nave, "también pasaría a llamarse", por "la magia de la circunstancias, Leodecia, Lionor, Leontina, Leovina" (4). Coqueteando desde el propio título con la tradición literaria latinoamericana, y lo fantástico maravilloso, la crónica se configura, efectivamente, a partir de los componentes melodramáticos de la novela rosa y la teleserie (la humilde y sufrida heroína en busca de un príncipe azul); y nos cuenta sobre el diluvio de cartas y propuestas de matrimonio que comienza recibir doña Leo, convertida en un auténtico suceso nacional. Registro de la soledad, el escrito expone una serie de párrafos seleccionados de esa avalancha de confesiones y promesas: "Usted es una flor hermosa y yo me encargaré de ser su jardinero y protegerla del frío y los temporales de la vida..." (5). Aunque "Doña Leo sí tiene quien le escriba", a fin de cuentas triunfa el desencuentro: "El galán escogido por la cortejada (un canadiense que ha cruzado mar y tierra para conocerla) no podrá esperarla eternamente mientras "ella se mueve en medio de los aromas de las frutas del mar" (5), para atender las mesas de su humilde mesón costero. Abandonando la condición de novia y estrella de televisión, doña Leo se volcará a su modesto negocio de barrio, donde continuará anhelando el amor incondicional, pero ahora con una cajita de zapatos y, dentro, las 140 cartas de sus enamorados.

La incorporación de los códigos propios del discurso melodramático en este texto despliega una sensibilidad que eleva esa forma de expresividad, un poco maniqueísta y excesiva, que posee para el mundo culto una connotación peyorativa pues caracteriza la vulgaridad de la estética popular, y que se encuentra históricamente ligada a la prohibición de la 
Olga Ostria Reinoso. Imágenes del BíoBío: Cultura popular, periferias urbanas e incongruencias en las crónicas de Alfonso Alcalde

palabra y a su consiguiente necesidad de una manifestación pletórica de pasiones y padecimientos "en una cultura que no ha podido ser 'educada' por el patrón burgués" (Martín Barbero 132). Se trata así de otra crónica ejemplar que concibe lo popular en su facultad de de entrelazarse con las prácticas masivo-urbanas (el show televisivo), desmarcándose de los moldes dominantes.

\section{Biobío: nostalgia e incongruencia}

Según se ha visto, en el proyecto escritural de Alfonso Alcalde, reflejado igualmente en sus crónicas urbanas, se adivinan los ecos de, al menos, dos tradiciones cercanas: la imaginería propia de la picaresca - presencia de personajes pobres pero astutos, tratamiento de un humor que, si bien no pretende ser moralizante, convoca situaciones cómicas plenas de picardía y algo de humor negro- y la tradición de la literatura carnavalizada, esta última en los términos que propone Bajtin, es decir, en su calidad de "trasposición del lenguaje del carnaval al lenguaje de la literatura" (Bajtin, Problemas 179), presente aquí, fundamentalmente, a través de imágenes artísticas y recursos ficcionales asociados a lo grotesco, la máscara y la lógica circense.

Desde ese ángulo, los personajes alcaldeanos son susceptibles de ser interpretados, por una parte, desde el determinismo de la citada picaresca y, por otra, desde el rito de la coronación y destronamiento ${ }^{15}$, propio de la cosmovisión

15 Explica, a propósito, Bajtin: "en la base del rito de coronación y destronamiento del rey se encuentra el núcleo mismo de la percepción carnavalesca del mundo: el pathos de cambios y transformaciones, de muerte y renovación. [...] Coronación-destronamiento es un rito doble y ambivalente que expresa lo inevitable y lo constructivo del cambio-renovación, la alegre relatividad de todo estado y orden, de todo poder y de toda situación jerárquica. En la coronación ya está presente la idea de un futuro 
carnavalesca -como lo ha hecho Geisse (Presencia 172) en relación a la cuentística del autor-, en la medida en que ellos parecen alcanzar un momento de gloria, de superación de la miseria o el abandono, que prontamente da pie al descenso y al regreso de las antiguas circunstancias. Se mantienen, así, en los ámbitos de la cultura popular, de la pobreza y la marginalidad y rara vez logran su cometido o consiguen ascender socialmente. Se trata, pues, de sujetos fallidos, antihéroes criollos, pobres, solos, pero festivos y esperanzados, optimistas después de todo, "los seres atormentados más activos del mundo" (Droguet 483). $\mathrm{Y}$ aunque, en este sentido, la amargura o el dolor no son unívocos en las crónicas de Acalde, y con frecuencia van de la mano del chiste y la fiesta, en gran parte de ellas la balanza termina inclinándose sin remedio hacia la radical melancolía y el abatimiento. En esa concepción fatalista del mundo reside, por cierto y desde nuestra perspectiva, una particularidad de las letras alcaldeanas. Así, si bien la escritura periodístico-literaria del escritor sureño persigue rescatar en positivo la cultura popular, no llega a sobredimensionar esa positividad, ya que el fracaso y la desolación a veces prevalecen en esta vertiente genérica.

Dicha línea discursiva se liga particularmente, creemos, con su poesía, pues aunque también allí existe una veta semicómica e irónica, "a veces, el hablante no puede evitar el desaliento y la contradicción vital entre vida y muerte" (Nómez 7), de forma tal que es posible afirmar que "el vivir muriendo es el leit motiv vital y angustiado del sufrimiento del sujeto poético" (ibídem 5).

Dos crónicas de los años 90 -los últimos de su producción y su vida-: "Shuto: Humor sin palabras"-reseña de un dibujante penquista- y "Poetisas del Biobío"-acerca de dos

destronamiento: la coronación desde un principio es ambivalente" (Problemas 181-182). 
"vecinas de la laguna San Pedro y de la fronda de los pinos incrustados al fondo, entre las aguas" (7) y su trabajo poético-, nos acercan a la manifestación de esta subjetividad pesarosa y de esencia abrumada que caracteriza una faceta imprescindible de la obra alcaldeana. En ambas, donde podemos descubrir las imágenes más líricas y conmovedoras del Biobío aquí revisadas, el río, metonimia de la ciudad y de la región, representa la nostalgia de lo primigenio: "Tatiana -una de las poetas biografiada- se lo pasaba jugando a las canicas en una calle de tierra que terminaba en el Biobío. El lugar de su infancia y correrías está intacto y termino de recorrerlo -escribe un Alcalde flaneur- tratando de complementar el patético mensaje de su poesía ¿Estaría ahí su verdadero origen?” (ídem).

El sentimiento se reproduce en el texto dedicado a Shuto, a quien "se le ocurrió nacer en Concepción. Vivió la primera parte de su niñez en una sombría pensión de la calle Tucapel, (donde) la criatura fue mecida en azul, ocres y verdes tormentosos $[, \ldots]$ a orillas del susurrante Biobío, su cómplice. Entre mudos se entienden cada vez que se ven" (2). Compañero de la vida inaugural, el río emerge como proveedor de tristezas determinantes, estructurales, de las cuales no puede el habitante de sus riberas huir.

El mismo caudal que surge "de Curaño y baja torrentosamente por el norte de Tricauco" ("Poetizas" 8) es, en efecto, presencia de un pasado inevitable para la otra poeta: "Ya sólo escribe en inglés pero a pesar de los pesares, en alguna parte le retumba la sonoridad del Bío-Bío" (ídem). Imperiosos parecen ser, asimismo, aquellos inviernos inacabables alrededor de los cuales ambas han forjado tormentosos y "estremecedores poemas", "entre la lluvia y la salvaje sinfonía de los nortes y surazos y las raíces históricas que fundamentan nuestro existir" (ídem). 
Los cuadros del río y de las aguas penquistas quedan, sin duda, emparentados, de un lado, a nostalgia y a lágrimas, y de otro, a una fuerza y un poder de sobrevivencia invencibles. Destino irrevocable, presencia magna, el río es torrente y es tormenta; es también susurro, silencio y, a la vez, música y sonoridad sinfónica. En franca conversación transgenérica, la misma complejidad de la zona del Biobío resuena en el gran poemario de Alcalde donde las "llamas de agua" (135), la "lluvia sombría entretejedora de desdichas" (El Panorama 136), "se dobla y salpica las más hermosas armonías (138), y el río "nos arma y desarma" (118), nos da vida y nos mata.

\section{Apertura final}

Ya sea mediante resonancias de la angustia existencial representativa de la obra poética del autor, o de sus protagonistas y atmósferas circenses, y la serie de recursos ficcionales que aquí hemos examinado, los textos periodísticoliterarios alcaldeanos dan cuenta de aquel "sonido literario" (como le gustaba decir al célebre cronista mexicano, Carlos Monsiváis) a partir del cual no sólo demuestran su condición de crónicas urbanas contemporáneas, y su habilidad de traspasar toda aduana discursiva, sino además revelan un íntimo dialogismo o "fuerte trazado intra e intertextual, que otorga al proyecto de Alcalde la consideración de una obra total" (Salas 172).

Tanto las tradiciones orales ligadas a los relatos populares, como los sabores y aromas de la cocina sureña que impregnan todo el proyecto estético alcaldeano, se manifiestan igualmente en estos escritos, privilegiando la construcción de un sentido de comunidad, de pertenencia, de memoria y de resistencia. En efecto, mediante sus rutas por los bares y el habla popular del Biobío, el multifacético escritor se adentra en el alma de los sectores más desposeídos de nuestra región, recobrando, de esta forma, los relatos opacados frente a los 
Olga Ostria Reinoso. Imágenes del BíoBío: Cultura popular, periferias urbanas e incongruencias en las crónicas de Alfonso Alcalde

hegemónicos y resquebrajando, con ello, el escenario de la subordinación. A través de tal dinámica los textos revelan, en verdad, una forma de relación con el mundo, signada, en primer lugar, por un esfuerzo constante por distinguir, visibilizar lo despreciado, y en segundo, por dialogar con la otredad, o mejor, por promover el diálogo entre todas las otredades desde lo popular (con lo letrado, con lo masivo y, por consiguiente, con lo urbano). En ese tenor, las crónicas, como tipo de texto transgresor y poroso, sustentan ese anhelo de tender puentes al poner en conexión los diversos géneros y vetas discursivas cultivados por Alcalde.

Paralelamente, vive en la escritura del penquista la contradicción profunda (configurada de modo predominante a partir de la simbología del circo), y desde la cual diseña también el mapa ciertamente marginal de la región, la ciudad de Concepción y sus periferias urbanas, hecha a trazos entre tabernas, modestos poblados costeros y recuerdos de tiempos siempre mejores: donde la risa, la alegría y la libertad populares se enredan con un dolor infinito, con la miseria profunda y la derrota del presente. Atravesados por un río implacable, muertos de nostalgia, los habitantes del Biobío parecen en el imaginario alcaldeano dueños de la desolación y predestinados a la tragedia, pero al mismo tiempo a pasar las penas en un bar escondido $\mathrm{y}$ olvidado, en búsqueda de un encuentro cómplice. Las riberas de la cultura urbana popular van aquí de las frías aguas invernales a las cálidas y, a veces también, infernales aguas del alcohol.

Entre la urgencia de dialogismo, de comunión, y una marginalidad radical que es a la vez un refugio (¿voluntario?), el "universo Bío-Bío"16 de Alcalde es tan incongruente como él, "que no calza en su espejo [...] y desde afuera lo ataca y desde adentro lo niega" (Alcalde, Siempre 96). El escritor deviene,

\footnotetext{
A propósito de la "galaxia Tomé” como bautizó la zona donde "ocasionalmente nació” (Breve autoalabanza 11).
} 
finalmente, la "Ciudad atribulada de agua", encarnación de soledad torrencial, de vida que arrasa y de palabra que inunda.

\section{Bibliografía}

Alcalde, Alfonso. El panorama ante nosotros. Santiago, Chile: Altazor, 2007. Impreso.

------. Breve autoalabanza biográfica. Algo que decir. Santiago: Editorial Cuarto propio, 2001.Impreso.

------. "Merenderos, chincheles, cantinas y picadas". La Gaceta de El Sur [Concepción, Chile]. 26 Feb. 1989: 1-3.

------. "Doña Leo y sus 140 maridos", La Gaceta de El Sur [Concepción, Chile]. 22 Ene. 1989: 4-5. Impreso.

------. "Alejandro Reyes: Un pintor ambulante", La Gaceta de El Sur [Concepción, Chile]. 5 Feb. 1989: 2-3. Impreso. "Días de radio". La Gaceta de El Sur [Concepción, Chile]. 5 Mar. 1989: 4-5. Impreso.

------. "Shuto": Humor sin palabras, La Gaceta de El Sur [Concepción, Chile]. 16 Abr. 1989: 2-3. Impreso.

------. "Poetisas del Bío-Bío". La Gaceta de El Sur [Concepción, Chile]. 16 Jul. 1989: 7-8. Impreso.

------. Las aventuras de El Salustio y El Trúbico. Santiago, Chile: Editorial Quimantú, 1973. Impreso.

------. Comidas y bebidas de Chile. Santiago, Chile: Editorial Quimantú. 1970. Impreso

------. "La sabrosa epopeya de las comidas y bebidas sureñas". El Sur, Suplemento dominical [Concepción, Chile]. 5 Jul. 1970: 4-5. Impreso.

------. Críspulo Gándara. El Sur, Suplemento dominical Concepción, Chile]. 15 Nov. 1970: 9. Impreso.

------."Impresiones". Antología de la poesía chilena contemporánea. En. Comp. Alfonso Calderón. Santiago, Chile: Editorial Universitaria, 1970. 366-379. Impreso.

Alone. "El auriga Tristán Cardenilla por Alfonso Alcalde". $E l$ Mercurio [Santiago, Chile]. 25 Jun. 1967. Impreso. 
Olga Ostria Reinoso. Imágenes del BíoBío: Cultura popular, periferias urbanas e incongruencias en las crónicas de Alfonso Alcalde

Bajtín, Mijail. Problemas de la poética de Dostoievski. Traducción Tatiana Bubnova. Bogotá: Fondo de Cultura Económica, 1993. Impreso.

Concha, Jaime. Historias de risas y lágrimas. José Miguel Varas, Alfonso Alcalde, Nicolás Ferraro, Franklin Quevedo. Santiago, Chile: Editorial Quimantú, 1973.Impreso.

-------. "Prólogo" a El auriga Tristán Cardenilla y otros cuentos. Santiago: Nascimiento, 1971. 7-17.Impreso.

De la Fuente, Antonio. "Todos los libros, todos los oficios. Entrevista a Alfonso Alcalde". Revista Apuntes 111(1996): 41-44. Impreso.

Droguett, Carlos. "La literatura chilena de espaldas a la realidad nacional”. Revista Mensaje 202/203 (1971): 477-484. Impreso.

García Canclini, Néstor. "Cultura trasnacional y culturas populares. Bases teórico-metodológicas para la investigación”. En. Cultura trasnacional y culturas populares. Eds. Néstor García Canclini y Rafael Roncagliolo. Lima: IPAL, 1988. 17-76. Impreso.

Geisse, Cristian. Presencia de la cultura popular y la carnavalización literaria en los cuentos de Alfonso Alcalde. Tesis de Magíster en Literatura Hispánica. Pontificia Universidad Católica de Valparaíso, 2005. Impreso.

------. "La consagración de la pobreza. El absurdo tesoro de la miseria". Proyecto Patrimonio, 2008. http://www.letras.s5.com/aa210608.html

Guerra, Lucía. Ciudad, Género e imaginarios urbanos en la narrativa latinoamericana. Santiago: Cuarto propio, 2014. Impreso.

Martín Barbero, Jesús. De los medios a las mediaciones. Comunicación, cultura y hegemonía. Barcelona: Gustavo Gili, 1987.Impreso.
Memoria chilena.
Alfonso
Alcalde.

http://www.memoriachilena.cl/602/w3-article-547.html 
Montecinos, Sonia. La olla deleitosa. Cocinas mestizas de Chile. Santiago, Chile: Catalonia, 2005.

Nómez, Naín. "Prólogo" a Siempre escrito en el agua. Santiago, Chile: LOM, 1998. 5-10. Impreso.

Ostria González, Mauricio. "Literatura oral, oralidad ficticia". Estudios Filológicos 36 (2001): 71-80.

Ostria Reinoso, Olga. "El discurso de la contraidentidad mexicana en las crónicas urbanas de Los rituales del caos, de Carlos Monsiváis". Contextos 28 (2009): 111-124. Impreso.

Salas, Francisco. "Alfonso Alcalde". Discursos/prácticas 2 (2008): 171-178.

Sepúlveda, Magda. "Concepción recobrado en la poesía chilena". Taller de Letras 47 (2010): 105-115. Impreso.

Vidal, Virginia. "Comidas y bebidas de Chile, de Alfonso Alcalde". El Siglo [Santiago, Chile]. 4 Sep. 1972: 14. Impreso.

Williams, Raymond. Marxismo y literatura. Barcelona: Península, 1980. Impreso. 